\title{
Centennial-scale variability of the British Ice Sheet: Implications for climate forcing and Atlantic meridional overturning circulation during the last deglaciation
}

\author{
Paul C. Knutz, ${ }^{1,2}$ Rainer Zahn, ${ }^{3}$ and Ian R. Hall ${ }^{4}$ \\ Received 28 March 2006; revised 29 September 2006; accepted 23 October 2006; published 15 February 2007.
}

[1] Evidence from paleoclimatic archives suggests that Earth's climate experienced rapid temperature changes associated with pronounced interhemispheric asymmetry during the last glacial period. Explanations for these climate excursions have converged on nonlinear interactions between ice sheets and the ocean's thermohaline circulation, but the driving mechanism remains to be identified. Here we use multidecadal marine records of faunal, oxygen isotope, and sediment proxies from the northeast Atlantic proximal to the western margins of the last glacial British Ice Sheet (BIS) to document the coupling between ice sheet dynamics, ocean circulation, and insolation changes. The core data reveal successions of short-lived (80-100 years), high-amplitude ice-rafted debris (IRD) events that were initiated up to 2000 years before the deposition of detrital carbonate during Heinrich events (HE) 1 and 2. Progressive disintegration of the BIS 19-16 kyr before present (B.P.) occurred in response to abrupt ocean-climate warmings that impinged on the northeast Atlantic during the early deglaciation. Peak IRD deposition recurs at 180-220 year intervals plausibly involving repeated breakup of glacial tidewater margins and fringing marine ice shelves. The early deglaciation culminated in a major meltwater pulse at $\sim 16.3 \mathrm{kyr}$ B.P. followed by another discharge associated with HE1 some 300 years after. We conclude that temperature changes related to external forcing and marine heat transport caused a rapid response of the BIS and possibly other margins of the Eurasian Ice Sheet. Massive but short-lived meltwater surges influenced the Atlantic meridional overturning circulation thereby contributing to North Atlantic climate variability and bipolar climatic asymmetry.

Citation: Knutz, P. C., R. Zahn, and I. R. Hall (2007), Centennial-scale variability of the British Ice Sheet: Implications for climate forcing and Atlantic meridional overturning circulation during the last deglaciation, Paleoceanography, 22, PA1207, doi:10.1029/2006PA001298.

\section{Introduction}

[2] The last glacial was marked by a series of abrupt climate shifts that contrast the relative stability of Holocene climates. Most notable are the rapid Dansgaard-Oeschger temperature oscillations found in ice cores from the Greenland ice sheet [Dansgaard and Oeschger, 1989; Grootes and Stuiver, 1997; Johnsen et al., 1972] which are also recorded in a range of climate archives including deep marine sediments [Bond and Lotti, 1995; Goni et al., 2002] and terrestrial environments [Allen et al., 1999; Clemens, 2005; Genty et al., 2003]. The peak cooling conditions culminated in major collapses of the Laurentide Ice Sheet (LIS) that resulted in the deposition of prominent "Heinrich" layers of ice-rafted debris (IRD) across the

\footnotetext{
${ }^{1}$ Geological Institute, University of Copenhagen, Copenhagen, Denmark.

${ }^{2}$ Now at Geological Survey of Denmark and Greenland, Copenhagen, Denmark.

${ }^{3}$ Institució Catalana de Recerca y Estudis Avançats y Universitat Autònoma de Barcelona, Institut de Ciencia y Tecnologia Ambientals, Bellaterra, Spain.

${ }^{4}$ School of Earth, Ocean and Planetary Sciences, Cardiff University, Cardiff, UK.
}

Copyright 2007 by the American Geophysical Union. 0883-8305/07/2006PA001298 northern North Atlantic [Broecker et al., 1992; Heinrich, 1988; Ruddiman, 1977]. A mechanism involving changes in the Atlantic meridional overturning circulation (MOC) driven by freshwater perturbation [Bond et al., 1993; Ganopolski and Rahmstorf, 2001] has frequently been highlighted but the cause and trigger for northern hemisphere ice sheet instabilities remains to be established. External climate forcing has been suggested as a modulator for Holocene ocean-climate change [Bond et al., 2001] but the significance of such forcing on glacial climate is controversial.

[3] Icebergs coming from the LIS are viewed as the principal contributor to IRD and meltwater during the Heinrich events (HE). However, several studies have suggested that other ice sheets in Scandinavia, Iceland and the British Isles fluctuated at a much faster pace than the 50007000 year intervals between HE [Bond and Lotti, 1995; Elliot et al., 1998; Fronval et al., 1995; Knutz et al., 2001; Peck et al., 2006]. A key question is whether iceberg discharges from these smaller ice sheets occurred sporadically as a result of internal glacial dynamics, or in response to regional climate variability in the millennial-centennial frequency band. Here we present fine-scale paired paleoceanographic records of IRD flux, polar planktonic foraminiferal abundance and stable isotopes from the northeast 


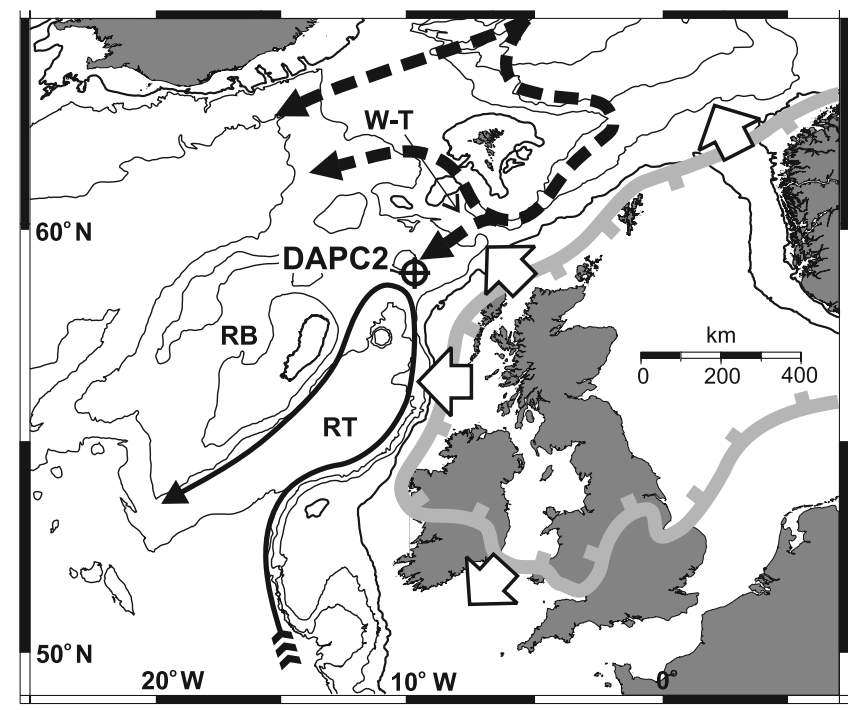

Figure 1. Location map in relation to the oceanographic setting and the extent of the LGM ice sheet in NW Europe. Broad arrows indicate the main glacimarine outlets. The thin black arrow illustrates a northerly boundary current driven by recirculated North Atlantic Deep Water, which flows along the European continental slope at depths of $2-$ $3 \mathrm{~km}$ [McCartney, 1992]. The dashed arrow represents Norwegian Sea Overflow Water, which enters the northeast Atlantic across the shallow sills between Iceland and Scotland [Ellett and Roberts, 1973; New and SmytheWright, 2001]. RB, Rockall Bank; RT, Rockall Trough; W-T, Wywille-Thomson Ridge. Contours represent 200, 1000, 2000, and $3000 \mathrm{~m}$ water depth.

Atlantic that cover the period $10-27 \mathrm{kyr}$ B.P. at typically multidecadal resolution. The records are derived from a sediment core located close to the margin of the last British Ice Sheet (BIS) that formed the southwest sector of the larger Eurasian Ice Sheet during the last glacial [Knutz et al., 2002] (Figure 1). The records allude to the interaction between Atlantic MOC and ice sheet dynamics and depict in fine detail the sequence of events that occurred at the end of the glacial period leading to the sequential breakup of the BIS.

\section{Oceanographic Setting}

[4] Core DAPC2 $\left(58^{\circ} 58.10^{\prime} \mathrm{N}, 09^{\circ} 36.75^{\prime} \mathrm{W}, 1709 \mathrm{~m}\right.$ water depth) was obtained by the Danish vessel R/V Dana from a contourite drift developed around the southern flank of the Rosemary Bank, Rockall Trough (Figure 1). The site is presently under the influence of Northeast Atlantic Deep Water that enters the Rockall Trough as part of a northern boundary current trailing the European margin at 2-3 km water depth [McCartney, 1992]. A subsidiary contribution from direct overflow across the Wyville-Thompson Ridge may contribute to the deep water circulation in the northern end of the trough [Ellett and Roberts, 1973]. Surface ocean climatology at this location is dominated by the warm North Atlantic Drift with present summer sea surface temperatures
(SSST) of around $12-13^{\circ} \mathrm{C}$. During the last glacial the core site was proximal to the BIS which during stages of maximum advancement extended to the Hebrides shelf margin [Stoker and Holmes, 1991] and to within $\sim 200 \mathrm{~km}$ to the southeast of the core site (Figure 1). Core DAPC2 therefore is well suited to document the variability of the BIS during the last glacial, which in turn, due to the proximity of the glacial polar front and to the pathway of the North Atlantic Drift current was likely positioned close to the climatic limit of ice sheet stability. Such a glacial configuration would have led to the BIS being particularly sensitive to changes in Atlantic MOC and its associated northward heat advection.

\section{Methods}

[5] The core was sampled at $2 \mathrm{~cm}$ intervals using plastic syringes containing volumes of $5-6 \mathrm{~cm}^{3}$. All samples were weighed before and after drying at $40^{\circ} \mathrm{C}$ and subsequently sieved using mesh sizes of 63,125 , and $250 \mu \mathrm{m}$. IRD and planktonic foraminifera were counted from the $>250 \mu \mathrm{m}$ size fraction. In most samples the entire lithic content $>250 \mu \mathrm{m}$ was counted. In samples where lithic grain numbers exceeded 800 , counting was performed on a split fraction of 300-400 grains. The total IRD content and its subcomponents fractured quartz, detrital carbonate and basalt were determined for each sample. A detailed petrological examination was carried out for samples representing prominent IRD peaks.

[6] The relative percentage of the polar foraminifera Neogloboquadrina pachyderma sinistral (Nps) was determined in the size fraction $>125 \mu \mathrm{m}$. Nps percent as a paleoproxy is sensitive to upper ocean and atmospheric temperatures and has been used previously to indicate the presence of polar surface waters and to semiquantitatively reconstruct SST variability in the North Atlantic region [Bond et al., 1993; Johannessen et al., 1994]. The remaining faunal components in DAPC2 mainly consist of the temperate to subpolar species Globigerina bulloides and Turborotalita quinqueloba. Oxygen isotopes were measured on $20-30 \mathrm{Nps}(250-350 \mu \mathrm{m}$ size fraction) and 3-6 specimens of the epifaunal benthic species Cibicidoides wuellerstorfi $(\mathrm{Cw})$. Oxygen isotope measurements were performed on a Thermo-Finnigan MAT 252 mass spectrometer coupled online to a fully automated CARBO Kiel sample preparation device. External precision of the $\delta^{18} \mathrm{O}$ determination was better than $\pm 0.06 \%$ o and are reported on the V-PDB scale. The $\delta^{18} \mathrm{O}$ values of $\mathrm{Cw}$ were corrected for seawater disequilibrium effects by $+0.64 \%$ [Shackleton and Opdyke, 1973].

[7] An initial chronology for DAPC2 was established using the Nps $\delta^{18} \mathrm{O}$ record in conjunction with 21 AMS ${ }^{14} \mathrm{C}$ dates from monospecific planktonic foraminiferal samples with weights ranging from 5 to $10 \mathrm{mg}$ (Table 1). AMS ${ }^{14} \mathrm{C}$ measurements were performed at the Radiocarbon Laboratory, University of Aarhus. The ${ }^{14} \mathrm{C}$ dates were subsequently converted into calendar years using CALIB5 assuming a constant 400 year marine reservoir correction [Stuiver and Reimer, 1993; M. Stuiver et al., CALIB Execute version 5.0.2, 2005, available at http://radiocarbon. 
Table 1. Chronological Data for DAPC2 ${ }^{\mathrm{a}}$

\begin{tabular}{|c|c|c|c|c|c|c|c|}
\hline $\begin{array}{c}\text { Core Depth, } \\
\mathrm{cm}\end{array}$ & $\begin{array}{c}\text { Lab } \\
\text { Number }\end{array}$ & $\begin{array}{l}{ }^{14} \mathrm{C} \text { Age, } \\
\text { years B. P. }\end{array}$ & Error, $\pm 1 \sigma$ & $\begin{array}{c}\text { CALIB } \\
\text { Age, } \\
\text { years B. P. }\end{array}$ & $\begin{array}{c}\text { GISP2 Age, } \\
\text { years B. P. }\end{array}$ & $\begin{array}{c}\text { Age Shift, }{ }^{\mathrm{d}} \\
\text { years }\end{array}$ & $\begin{array}{c}\Delta \mathrm{MR}^{\mathrm{e}}{ }^{\text {years }}\end{array}$ \\
\hline 10 & AAR-6303 & 3740 & 55 & 3672 & & & \\
\hline 42 & AAR-5209 & 8590 & 90 & 9238 & & & \\
\hline 78 & $A A R-5210$ & 10830 & 90 & 12336 & 11788 & 958 & 799 \\
\hline 96 & AAR-6304 & 11380 & 110 & 12931 & 12774 & 1394 & 563 \\
\hline $126^{\mathrm{f}}$ & AAR-7990 & 10910 & 75 & & & & \\
\hline 138 & AAR-6305 & 13410 & 130 & 15367 & 15288 & 1878 & 565 \\
\hline 154 & AAR-7991 & 14400 & 110 & 16679 & 15846 & 1446 & 1234 \\
\hline 160 & $A A R-5211$ & 14900 & 110 & 17424 & 15973 & 1073 & 1684 \\
\hline 171 & AAR-7992 & 15330 & 100 & 17673 & 16206 & 876 & 1947 \\
\hline 178 & AAR-7993 & 15390 & 130 & 17832 & 16354 & 964 & 1868 \\
\hline 199 & $A A R-6306$ & 15400 & 170 & 18307 & 16798 & 1398 & 1436 \\
\hline 209 & $A A R-5212$ & 15560 & 140 & 18524 & 16961 & 1401 & 1457 \\
\hline 269 & AAR-7994 & 16430 & 130 & 19203 & 17865 & 1435 & 1554 \\
\hline 352 & AAR-8755 & 17310 & 130 & 20042 & 19429 & 2119 & 999 \\
\hline 387 & AAR-8756 & 17870 & 130 & 20672 & 20091 & 2221 & 981 \\
\hline 481 & AAR-8757 & 19730 & 140 & 22825 & 22394 & 2664 & 831 \\
\hline 504 & AAR-8758 & 20280 & 150 & 23394 & 23003 & 2723 & 791 \\
\hline 519 & AAR-9338 & 20450 & 170 & & 23386 & 2936 & \\
\hline 536 & AAR-8759 & 21410 & 200 & & 23997 & 2587 & \\
\hline 562 & AAR-8760 & 21860 & 190 & & 25000 & 3140 & \\
\hline 576 & AAR-9339 & 23660 & 210 & & 25606 & 1946 & \\
\hline 588 & AAR-8761 & 23950 & 220 & & 26241 & 2291 & \\
\hline
\end{tabular}

${ }^{\text {a }}$ Previously published ${ }^{14} \mathrm{C}$ datings from Knutz et al. [2002] are shown in italics.

${ }^{\mathrm{b}}$ Including constant marine reservoir (MR) age of 400 years.

${ }^{\mathrm{c}}$ Based on linear interpolation between tie points displayed in Figure 3.

${ }^{\mathrm{d}}$ Difference between fit-to-GISP2 ages and uncorrected ${ }^{14} \mathrm{C}$ values.

${ }^{\text {e }}$ Difference between CALIB ages excluding $400 \mathrm{yr}$ MR correction, and fit-to-GISP2 ages.

${ }^{\mathrm{f}}$ Dating omitted due to age inversion.

pa.qub.ac.uk/calib/]. The age scale was then refined using the downcore variability of Nps percent and its correlation with the Greenland ice core GISP2 $\delta^{18} \mathrm{O}$ record (see section 4.1).

\section{Results}

\subsection{Age Model}

[8] The downcore AMS ${ }^{14} \mathrm{C}$ age distribution displays a noticeable inflection in the age-depth function at $170 \mathrm{~cm}$ indicating the transition from a glacial stage high sediment deposition regime with sedimentation rates of $60-70 \mathrm{~cm} \mathrm{kyr}^{-1}$ to one of more moderate rates, $20-30 \mathrm{~cm} \mathrm{kyr}^{-1}$, into the deglaciation (Figure 2). Three ${ }^{14} \mathrm{C}$ ages between 171 and $199 \mathrm{~cm}$ are virtually identical within their error bars, $15.33-$ $15.40{ }^{14} \mathrm{C}$ kyr B.P., corresponding to $17.67-18.31$ calendar kyr B.P., implying extremely high sedimentation rates or instantaneous deposition of this interval (Table 1 and Figure 2a). The lithology and sediment composition does not reveal any evidence for the presence of a turbidite layer or other mass transportation event. Rather the interval corresponds to a strong meltwater and IRD pulse associated with HE1 and therefore the plateau in the age/depth function is most likely related to changes in the marine inventory of dissolved radiocarbon [Bard et al., 1993]. Similar ${ }^{14} \mathrm{C}$ plateaus across Heinrich events have been observed at other North Atlantic core sites [Andrews et al., 1999]. In order to eliminate the suspected meltwater artefact we discarded the two ${ }^{14} \mathrm{C}$ dates at 171 and $178 \mathrm{~cm}$ from the age model. We next established a calendar year timescale using the CALIB5 conversion routine.
[9] Comparing the record of Nps percent variation in DAPC2 on the calibrated ${ }^{14} \mathrm{C}$ timescale with the layer counted $\delta^{18} \mathrm{O}$ record from the Greenland GISP2 ice core [Grootes and Stuiver, 1997] displays a striking similarity between the two profiles (Figure 3). This resemblance confirms the tight coupling between atmospheric temperatures over Greenland and North Atlantic SST that has been demonstrated in previous studies from the northern and midlatitude North Atlantic [Shackleton et al., 2000; van Kreveld et al., 2000; Voelker et al., 1998]. Temporal offsets in structure between the marine and ice core records are particularly prominent (up to 1500 years) prior to the major cooling associated with HE1 and confirm the possibility of a strong overprint on the ${ }^{14} \mathrm{C}$ age scale from changes in the local surface layer ${ }^{14} \mathrm{C}$ reservoir. Therefore we chose to refine the ${ }^{14} \mathrm{C}$ derived age model by maximizing the correlation between the downcore variability of Nps percent and the GISP2 $\delta^{18} \mathrm{O}$ record (Figure 3 ). Tie points were, for instance, the high-amplitude Nps percent changes in DAPC2 that mirror the Bølling-Allerød to Younger Dryas climate swings seen in GISP2 (Figure 3). The series of rapid Nps percent oscillations in the lower section of the marine record likewise are well correlated to similar $\delta^{18} \mathrm{O}$ oscillatory structures in the Greenland record. Peak Nps abundances, in excess of $90 \%$, coincide with IRD maxima (including dolomitic carbonate) indicating the incursion of HE1 and HE2. The abrupt warming that followed these events is displayed by stepwise decreases in Nps abundance to values of $<30 \%$.

[10] Comparing the refined age model with the ${ }^{14} \mathrm{C}$-AMS derived timescale suggests marine reservoir age shifts of 

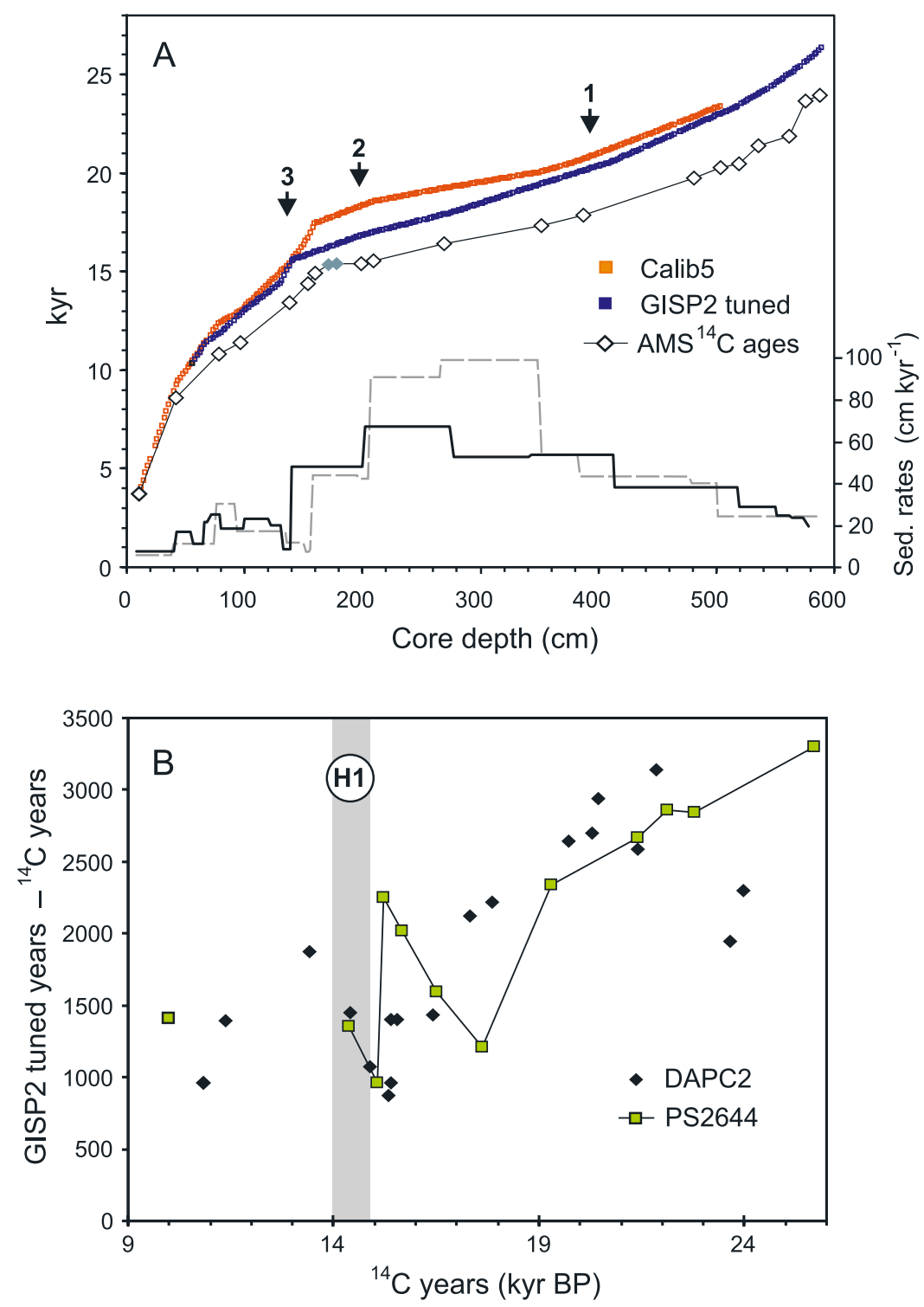

Figure 2. (a) Age/depth relations in DAPC2 based on raw ${ }^{14} \mathrm{C}$ values, calibrated ${ }^{14} \mathrm{C}$, and GISP2 tuned ages (see correlation with GISP2 in Figure 3). Calibration was performed using CALIB5 (http:// radiocarbon.pa.qub.ac.uk/calib/). The differences between calibrated and fit-to-GISP2 age values imply increased marine reservoir ages $(\Delta \mathrm{MR})$ beyond the modern value of 400 years. $\Delta \mathrm{MR}$ increases to $\sim 1000$ years subsequent to the first deglacial IRD response at $20.3 \mathrm{kyr}$ (arrow 1). Between the meltwater pulse at $16.8 \mathrm{kyr}$ (arrow 2) and the pre-Bølling warming at $15.5 \mathrm{kyr}$ (arrow 3) a further $\Delta \mathrm{MR}$ increase up to 2000 years is observed (Table 1). The solid diamonds represent ${ }^{14} \mathrm{C}$ ages at 171 and $178 \mathrm{~cm}$ core depth that were excluded from the calibrated age model. Sedimentation rates shown on the right $y$ axis are and based on the GISP2 tuned age model (black line) and the independent calibrated ${ }^{14} \mathrm{C}$ age scale (gray line). (b) Offsets between GISP2 tuned calendar years and uncorrected ${ }^{14} \mathrm{C}$ ages determined in DAPC2 (northeast Atlantic) and PS2644 (Icelandic Sea) [Voelker et al., 1998]. Both records indicate reduced age offsets prior to HE1 linked to increased $\triangle \mathrm{MR}$.

800-900 years across the LGM and up to 2000 years during the peak of HE1 (Table 1 and Figure 2a). Marine radiocarbon age shifts on this order are in accordance with earlier observations [Waelbroeck et al., 2001] and are supported by a comparison of age discrepancies between DAPC2 and core PS2644 from the Greenland Sea [Voelker et al., 1998]
(Figure 2b) that experienced similar magnitudes in ${ }^{14} \mathrm{C}$ age excursions in the interval 14 to $23{ }^{14} \mathrm{C}$ kyr. Increases in marine reservoir ages of up to 800 years during the Younger Dryas have been explained by a combination of reduced ocean ventilation and increased sea ice cover [Bard et al., 1994; Stocker and Wright, 1996]. In addition to these factors 


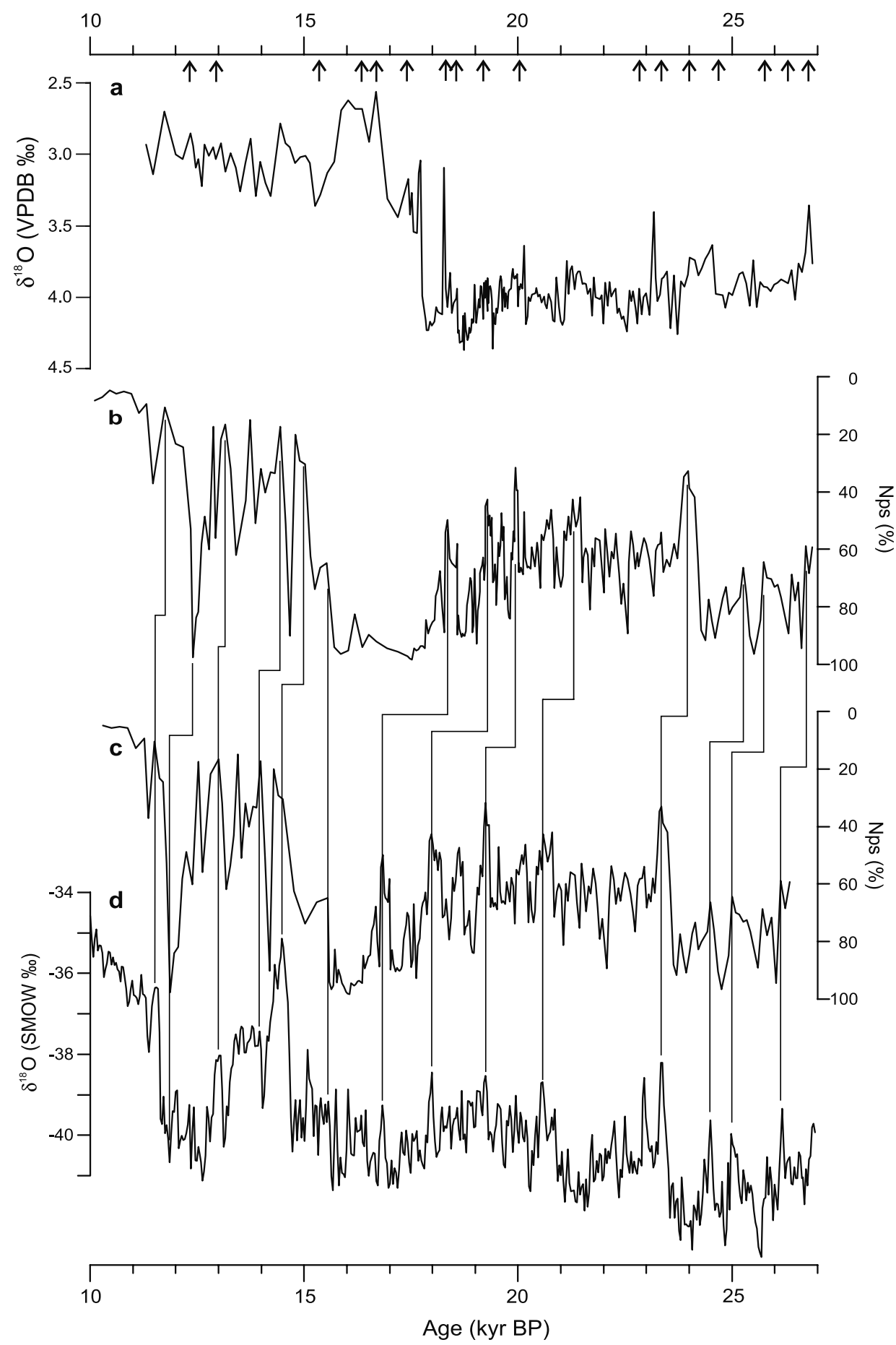

Figure 3. Correlation of proxies from DAPC2 with the GISP2 climate record. (a) Planktonic $\delta^{18} \mathrm{O}$ record from DAPC2 on an independent calendar timescale. (b) Relative abundance of Neogloboquadrina pachyderma sinistral (Nps) from DAPC2 on an independent calendar timescale. (c) Nps percent matched to the high-resolution oxygen isotope data $\left(\delta^{18} \mathrm{O} \mathrm{SMOW}\right)$ from the Greenland Summit GISP2 ice core (http://depts.washington.edu/qil/datasets/gisp2_main.html) [Grootes and Stuiver, 1997] (d). The tie points to GISP2 are demarcated by thin vertical lines. Positions of AMS ${ }^{14} \mathrm{C}$ ages are indicated by arrows along the upper age axis. The calendar timescale (Figures $3 \mathrm{a}$ and $3 \mathrm{~b}$ ) is based on calibrated AMS ${ }^{14} \mathrm{C}$ dates (CALIB5) and, for samples older than $23 \mathrm{kyr}$, by linear extrapolation of sedimentation rates. The GISP2 timescale (Figures 3c and 3d) is based on layer counting according to Meese et al. [1997]. GISP2 $\delta^{18} \mathrm{O}$ data were filtered by Gaussian interpolation at a bandwidth of $\sim 70$ year to obtain a similar temporal resolution as in DAPC2. 
input of nonradiogenic carbon from meltwater (i.e., a "hard water" effect) may have contributed to the apparently large marine reservoir ages observed during the early deglaciation.

[11] Glacial sedimentation rates based on the GISP2 tuned timescale generally vary between 20 and $65 \mathrm{~cm} \mathrm{kyr}^{-1}$ (Figure 2a), yielding a mean time step of $70 \pm 58$ yrs at a data point interval of $2 \mathrm{~cm}$ along the proxy records. In the high-resolution interval between 15.5 and $20.5 \mathrm{kyr}$ time steps are typically $30-40$ years. Reduced sedimentation rates, $8-10 \mathrm{~cm} \mathrm{kyr}^{-1}$, during the Bølling interstadial at $\sim 14.5 \mathrm{kyr}$ and the Holocene interval probably reflect a combination of more intense bottom currents and lower terrigenous sediment supply to the core site. Because of the potentially large, but essentially unknown, meltwater influence on the marine ${ }^{14} \mathrm{C}$ reservoir, and for age model consistency on an interhemispheric scale, we have chosen to present the proxy data on the GISP2 timescale. This preference has no influence on the main conclusions drawn from the sequence of events in the proxy records or the inferred cyclicity (see section 5.3).

\subsection{IRD and Oxygen Isotopes}

[12] Marine climate indicators from DAPC2 for the interval 10-27 kyr B.P. display the familiar succession of events across the LGM and leading up to the last deglaciation (Figures 4 and 5). HE1 and HE2 stand out by the maximum abundance of Nps, in excess of $90 \%$, and by IRD reflecting the incursion of maximum cooling and peak iceberg drift. The population of IRD in these sections contains pale yellow dolomitic carbonate (Figure 4e, see also 4.3) that was previously identified as being derived from Paleozoic limestone underlying the LIS in the Hudson Bay region [Andrews and Tedesco, 1992; Bond et al., 1992]. Both events are marked by coeval negative excursions in planktonic $\delta^{18} \mathrm{O}$ by $0.4-0.8 \%$ (Figure $4 \mathrm{c}$ ) signaling the enhanced meltwater incursions that went along with these events. As shown in earlier studies depletions in planktonic foraminifera abundance occur not only during the Heinrich events but some thousand years prior to these events [Hemming, 2004], a feature that is also displayed in the foraminiferal abundance pattern around the HE intervals in DAPC2 (Figure 4b).

[13] A prominent negative planktonic $\delta^{18} \mathrm{O}$ shift of $\sim 0.8 \%$ at $\sim 16.3$ kyr B.P. (Figure $4 \mathrm{c}$ ) coincides with the main deglacial phase of the Fennoscandian Ice Sheet recorded in the Norwegian Channel [Lehman et al., 1991] and on the North Sea Fan [Lekens et al., 2005]. This shift is accompanied by a sharp negative $\delta^{18} \mathrm{O}$ overshoot, suggesting an additional meltwater pulse likely derived from a local source on the British margin [Knutz et al., 2002]. The step change in planktonic $\delta^{18} \mathrm{O}$ at 16.3 is followed by a prominent depletion peak, also of $\sim 0.8 \%$, between $15.8-15.5 \mathrm{kyr}$ B.P. corresponding to the HE1 event. The benthic $\delta^{18} \mathrm{O}$ signal displays a more consistent decrease of $1.3 \%$ from about $16.3 \mathrm{kyr}$ and throughout the HE1 interval, thus with an onset that leads the DC peak by $400-500$ years. This transition in benthic oxygen isotope values was previously observed (though at a lower resolution) on the Feni Drift by Jansen and Veum [1990] and referred to as termination 1A. The combined benthic and planktonic $\delta^{18} \mathrm{O}$ records from these nearby sites suggests a rapid transfer of the deglacial signal to intermediate depths in the Rockall Trough, conceivably by brine exclusion during sea ice formation [Dokken and Jansen, 1999]. From $\sim 12$ kyr a second negative shift in benthic $\delta^{18} \mathrm{O}$ is observed, which corresponds to termination $1 \mathrm{~b}$ leading into the Holocene [Jansen and Veum, 1990].

[14] Positive correlation between Nps percent and $\delta^{18} \mathrm{O}$ on centennial to subcentennial scales reflects transient ocean temperature changes that are particularly well developed across the LGM and early deglaciation (Figure 5). Oxygen isotope amplitudes during these events are in the range $0.2-$ $0.5 \%$ suggesting SST changes of up to $2^{\circ} \mathrm{C}$, possibly even larger considering that low $\delta^{18} \mathrm{O}$ meltwaters could be involved in some of the cold episodes. Cold-to-warm temperature transitions during these events occur within a single sample step, corresponding to about 30 years according to our age model. This is similar to the rates of change seen in the Greenland ice cores reinforcing the contention of a tight coupling between atmospheric oscillations and surface ocean variability at the core site.

[15] The IRD record likewise shows subcentennial-scale variability (Figure 5a). Both HE1 and HE2 are preceded by recurrent peak IRD events that are multidecadal in duration and superimposed on a background of increasing IRD flux (Figures 4d and 5a). Similar lithic "precursor" events have been reported from other core sites across the North Atlantic and inferred to originate from sudden Icelandic and European glacial surges [Bond and Lotti, 1995; Grousset et al., 2000; Scourse et al., 2000]. Two additional intervals with increased IRD flux of multicentennial duration are observed across the LGM, 23-19 kyr, with intermittent peaks correlating with smaller-scale cooling/ freshening events indicated by increases in Nps percent and planktonic $\delta^{18} \mathrm{O}$ (Figure 4). Finally, a sharp IRD peak occurs near the end of the Younger Dryas period and coincides with maximum cooling that is evident from the brief period of maximum Nps percent. This event mirrors the HE0 [Andrews, 1998] that is preceded in our record by two minor lithic increases at the termination of the Allerød warming.

[16] The prominent short-lived ( $<100$ years) maxima in IRD deposition prior to HE1 and HE2 coincide with increased Nps percent and variable degrees of planktonic $\delta^{18} \mathrm{O}$ depletion indicative of marine cooling associated with meltwater discharge (gray bars in Figure 5). This pattern is best developed for the events preceding HE1, while in particular the $\delta^{18} \mathrm{O}$ depletions prior to HE2 appear largely subdued, most likely reflecting colder temperatures and lower melting rates during the full glacial conditions surrounding HE2. In contrast, a positive correlation between and $\delta^{18} \mathrm{O}$ and IRD is observed for the events centered at 22.0 and $20.3 \mathrm{kyr}$ (Figures 5a and 5c) suggesting that iceberg discharges during LGM were accompanied by a low meltwater production.

\subsection{Lithic Petrology}

[17] In order to assess possible iceberg sources we evaluated the petrological composition of the series of IRD peaks observed in core DAPC2 (Figure 6 and Table 2). Across the IRD maxima quartz is the dominant component in most samples, generally around $70 \%$, followed by 


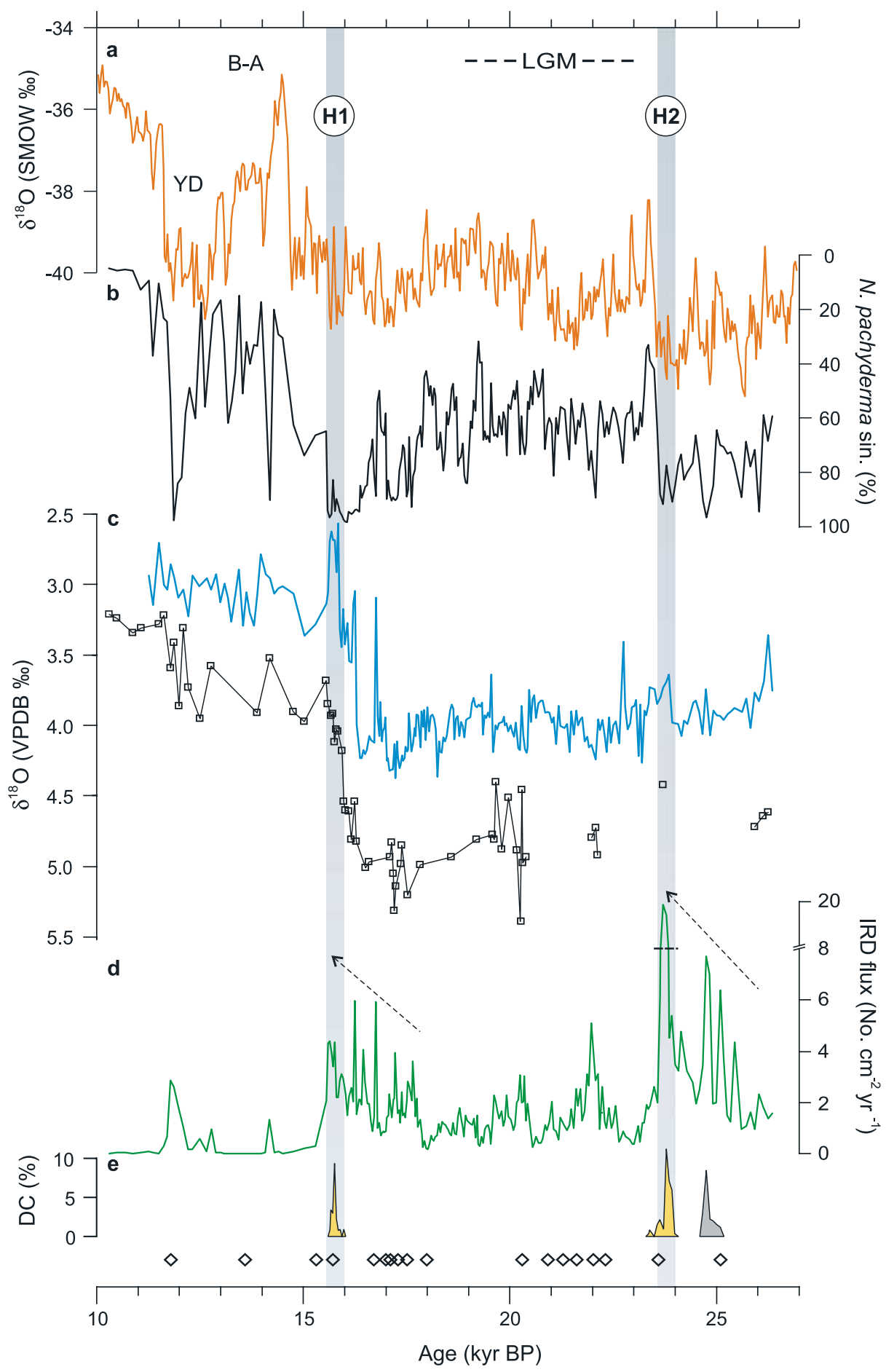

Figure 4. Stratigraphic correlation between marine parameters from DAPC2 and oxygen isotope data from the GISP2 Greenland ice core (a) 10-27 kyr B.P. (b) Relative abundance of Neogloboquadrina pachyderma sinistral (Nps). (c) Planktonic (blue line) and benthic oxygen isotope values (black squares) reported as $\delta^{18} \mathrm{O}$ V-PDB. (d) Total IRD flux. Note scale break on $y$ axis. (e) Relative abundance of detrital carbonate. Orange indicates pale yellow carbonate grains, Gray indicates dark carbonate grains. Open diamonds along lower age axis indicate ${ }^{36} \mathrm{Cl}$ rock exposure ages from Ireland [Bowen et al., 2002]. The typical error for ${ }^{36} \mathrm{Cl}$ ages (not shown) is in the range of $\pm 1-2$ kyr. Younger Dryas (YD), Bølling-Allerød (B-A), Heinrich events 1-2 (H1, H2), and Last Glacial Maximum (LGM) are indicated. Slanted arrows demarcate sequences of discrete centennial-scale peaks superimposed on a gradual increase in background IRD. The chronology for DAPC2 is based on visually matching centennial-scale warmings (cooling for YD) between Nps percent and GISP2 $\delta^{18} \mathrm{O}$ (Figure 3). 

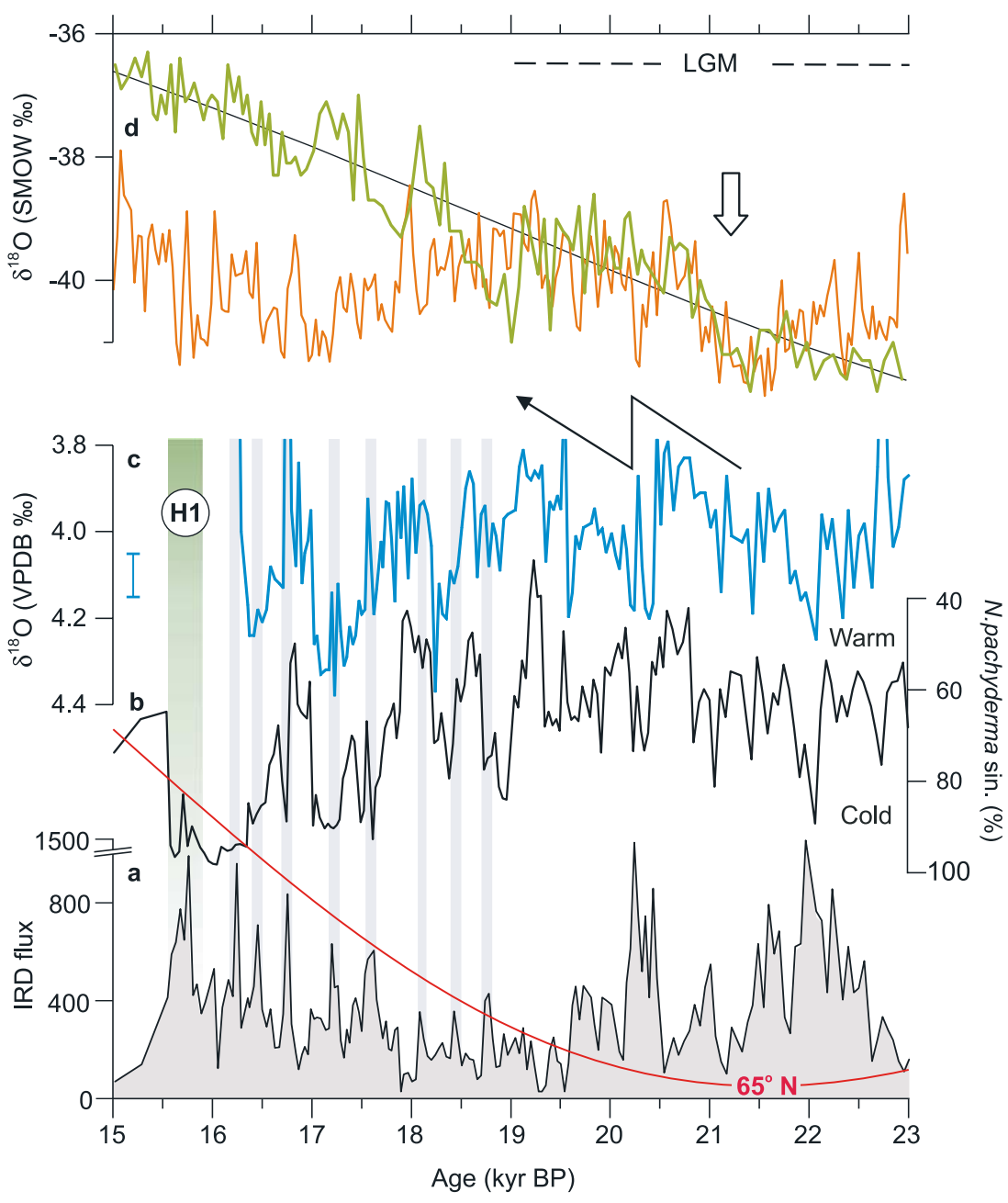

Figure 5. Detailed view of paleoclimatic parameters from the northeast Atlantic, Greenland, and Antarctica across the LGM and early deglaciation (15-23 kyr B.P.). (a) IRD flux (number $\mathrm{cm}^{-2} \mathrm{yr}^{-1}$ ) in DAPC2, based on grain abundance of fractured quartz $>250 \mu \mathrm{m}$, bulk density and linear sedimentation rates. HE1 is defined by the presence of detrital carbonate (5-10\% out of total IRD). Red line indicates July insolation at $65^{\circ} \mathrm{N}$. (b) Relative abundance of Neogloboquadrina pachyderma sinistral in DAPC2 (as in Figure 4). (c) Oxygen isotope data from DAPC2 (as in Figure 4) with range of analytical error indicated by blue bar. (d) Orange curve, GISP2 oxygen isotope data, and green curve, oxygen isotope data $\left(\delta^{18} \mathrm{O}\right.$ SMOW) from the Antarctic Byrd ice core. Estimated uncertainty of the Byrd age model relative to GISP2 is \pm 300 years [Blunier and Brook, 2001]. Thin black line represent a mean global insolation curve (average $65^{\circ} \mathrm{N}$ and $90^{\circ} \mathrm{S}$ ). Gray vertical bands highlight correlation between short-lived IRD events, Nps percent and planktonic $\delta^{18} \mathrm{O}$ in DAPC2 across the early deglaciation. Slanted arrows (Figure 5c) illustrate warming trends following the first deglacial warming response marked by white arrow (Figure 5d).

subordinate amounts of acidic igneous and metamorphic grains. Pale yellowish dolomitic carbonate grains, typically associated with Paleozoic formations underlying the central parts of the LIS, are present with concentrations of up to $10 \%$ indicating that LIS icebergs drifted far into the northeast Atlantic during HE1 and HE2 (Figure 4e and Table 2). A separate type of dark gray detrital carbonate is observed in significant amounts (up to $8 \%$ ) immediately prior to HE2 (Figure $4 \mathrm{e}$ and Table 2). Basalt generally occurs in trace amounts $(<5 \%)$ throughout the core with the exception of IRD peak 13 which contains $30 \%$ of dark olivine rich grains.
The Younger Dryas IRD peak (1 in Figure 6) contains up to $11 \%$ of brown glassy tephra shards, presumably an ice-rafted component of North Atlantic ash zone 1 previously identified in cores from the Hebrides margin [Austin and Kroon, 1996].

\section{Discussion}

5.1. IRD Provenance and Timing With BIS Variability

[18] A striking feature of the HE1 and HE2 intervals in DAPC2 are the sequences of brief centennial-scale IRD 


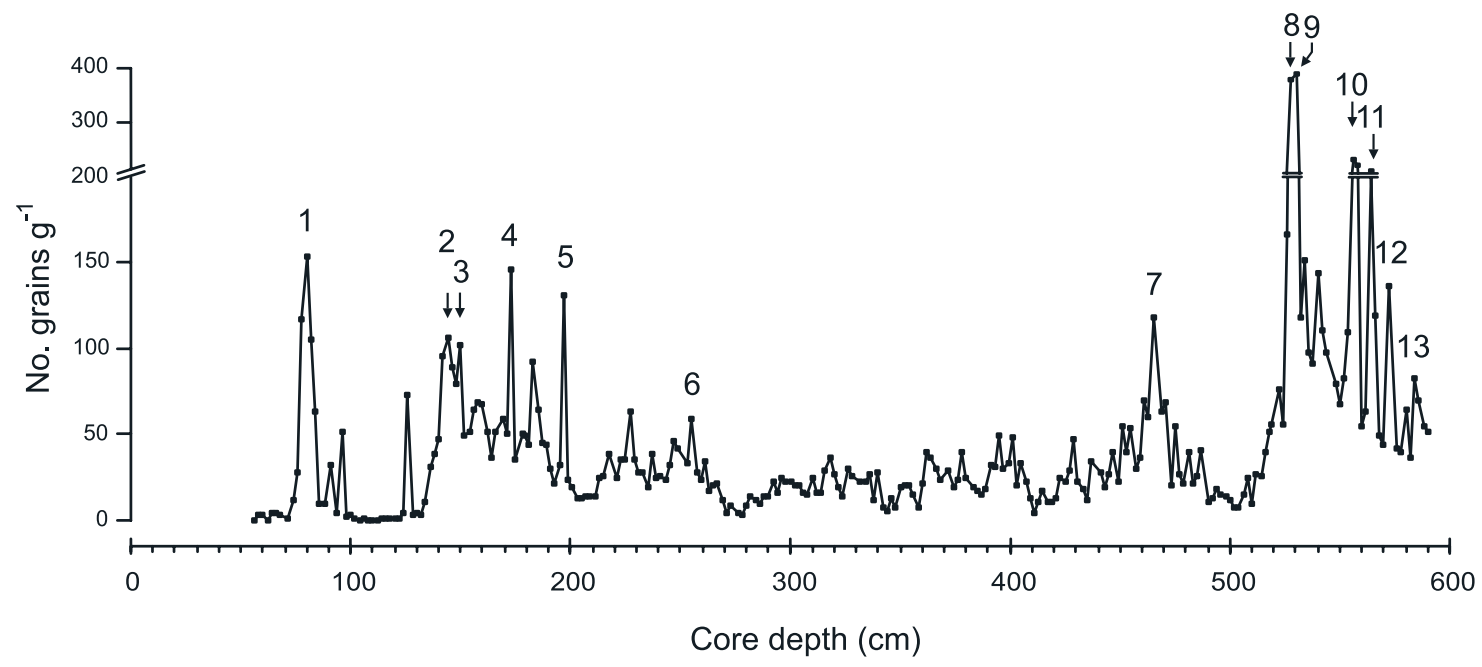

Figure 6. IRD abundance $>250 \mu \mathrm{m}$, on a depth scale. Numbers refer to lithic peaks where the total petrological composition was determined (Table 2).

peaks occurring up to a few thousand years before the detrital carbonate layers. The occurrence of minor IRD peaks prior to Heinrich events observed by Bond and Lotti [1995] were considered to represent discharges from ice shields in Greenland, Barents Sea or Scandinavia. Similar "precursor" peaks were identified in subsequent studies where application of radiogenic isotopes [Grousset et al., 2000] and sedimentary petrology [Knutz et al., 2002; Peck et al., 2006; Scourse et al., 2000] of ice-rafted material suggested a more distinct European provenance.

[19] The origin of individual IRD deposition events obviously has implications for the mechanism of ice sheet disintegration associated with HE sequences. The proximity of DAPC2 to the glacial stage BIS and the high IRD fluxes within the events leading up to HE2 and HE1, where in the latter instance fluxes are on occasion greater than under full Heinrich conditions, suggests this ice sheet as a potential source for icebergs. In addition to local sources IRD may have been supplied by a southward drift of icebergs from
Scandinavia emanating from the Norwegian Channel. Although the coarse fraction is largely dominated by quartz grains, which limits the identification of specific source regions, some intervals reveal more distinctive sedimentary components. The dark gray carbonate that contributes to the IRD peak prior to HE2, at $\sim 25 \mathrm{kyr}$, differs markedly from the pale yellow dolomitic carbonate typical of the HE2 layer that follows it. The most likely source terrain for the dark gray carbonate are the carboniferous limestone formations in western and central Ireland [Sevastopulo, 1981]; an inference that is supported by the presence of debris flow deposits rich in dark gray limestone clasts on the Irish continental slope [Hall and Scourse, 2005].

[20] Basalt eroded from the Tertiary provinces in western Scotland and northern Ireland has been identified as a lithic tracer in cores MD95-2006 on the Barra Fan [Knutz et al., 2001] and MD02-2461 in the Porcupine Seabight [Peck et al., 2006]. The small amount of ice-rafted basalt in DAPC2 suggests that either the core site was not in the primary drift

Table 2. Petrological Composition of IRD Peaks $(<250 \mu \mathrm{m})$ in DAPC2 ${ }^{\mathrm{a}}$

\begin{tabular}{|c|c|c|c|c|c|c|c|}
\hline \multirow[b]{2}{*}{ IRD Peak } & \multirow[b]{2}{*}{$\begin{array}{c}\text { Core } \\
\text { Depth, cm }\end{array}$} & \multirow{2}{*}{$\begin{array}{l}\text { Number of } \\
\text { Lithics } \\
>250 \mu \mathrm{m} \\
\end{array}$} & \multicolumn{2}{|c|}{ Quartz } & \multirow[b]{2}{*}{$\begin{array}{c}\text { Percent } \\
\text { Other }\end{array}$} & \multirow[b]{2}{*}{ Percent DC } & \multirow[b]{2}{*}{$\begin{array}{c}\text { Percent } \\
\text { Basalt } \\
\end{array}$} \\
\hline & & & $\begin{array}{c}\text { Percent } \\
\text { Fractured }\end{array}$ & $\begin{array}{c}\text { Percent } \\
\text { Rounded }\end{array}$ & & & \\
\hline 1 & 80 & 557 & 12 & 71 & $11(4)$ & - & - \\
\hline 2 & 144 & 487 & 14 & 60 & 17 & - & 8 \\
\hline 3 & 150 & 363 & 22 & 50 & 14 & 11 & - \\
\hline 4 & 173 & 480 & 17 & 52 & 26 & - & 5 \\
\hline 5 & 197 & 583 & 14 & 58 & 23 & - & 3 \\
\hline 6 & 255 & 222 & 10 & 61 & 27 & - & - \\
\hline 7 & 465 & 541 & 26 & 48 & 22 & - & 5 \\
\hline 8 & 528 & 2400 & 22 & 48 & 24 & - & 5 \\
\hline 9 & 530 & 2222 & 31 & 41 & 13 & 11 & 3 \\
\hline 10 & 556 & 1230 & 29 & 38 & 21 & $8^{\mathrm{b}}$ & 4 \\
\hline 11 & 564 & 1200 & 23 & 40 & 33 & - & 3 \\
\hline 12 & 572 & 756 & 27 & 42 & 27 & - & 4 \\
\hline 13 & 584 & 500 & 24 & 27 & 20 & - & 29 \\
\hline
\end{tabular}

${ }^{a}$ See Figure 6. Percent other represent unspecified igneous and metamorphic fragments except for peak 1 which also contains $11 \%$ of brown tephraa. DC, detrital carbonate.

${ }^{\mathrm{b}}$ Dark gray carbonate. 
path of icebergs emanating from the central part of the BIS, or if these icebergs drifted over the core site they did not experience major melting. An exception is a brief IRD event at the onset of the sequence leading up to HE2 ( $26 \mathrm{kyr})$, which contains abundant olivine basalt (Figure 6 and Table 2).

[21] A comparison with ${ }^{36} \mathrm{Cl}$ exposure ages from glacial boulders and smoothed bedrock in Ireland [Bowen et al., 2002] adds further constraints to establish a connection between the IRD deposition events in DAPC2 and BIS variability. ${ }^{36} \mathrm{Cl}$ exposure ages (open diamonds in Figure $4 \mathrm{e}$ ) cluster in 2 groups indicating phases of ice sheet retreat in the western British Isles during the LGM and early deglaciation. Single point ${ }^{36} \mathrm{Cl}$ ages suggest that decay of continental ice also occurred in the course of HE2 and HE1 and during the late deglaciation (Allerød and Younger Dryas). The timing of ice sheet retreat suggested by the ${ }^{36} \mathrm{Cl}$ ages agrees particularly well with the centennial IRD events prior to HE1. The two IRD maxima during the LGM overlap with a ${ }^{36} \mathrm{Cl}$ age cluster centered around $21.8 \mathrm{kyr}$ B.P. that according to Bowen et al. [2002] reflects an early phase of ice sheet retreat immediately after the BIS reached its maximum LGM size. From this tight correlation between the timing of glacial retreat on the British Isles, reflected in ${ }^{36} \mathrm{Cl}$ ages, and the occurrence of lithic peaks in DAPC2 we conclude that the northern Rockall Trough received a dominant supply of IRD flux from the BIS.

\subsection{Sequencing Events Leading Into the Last Deglaciation}

[22] The high temporal resolution in DAPC2 during the early deglacial and the LGM, 15-23 kyr, enables a detailed comparison of the data profiles with the sequence of events displayed in ice core records (Figure 5). Atmospheric temperature records, on their methane synchronized timescales [Blunier and Brook, 2001], from Greenland (GISP2 [Grootes and Stuiver, 1997]) and west Antarctica (Byrd [Johnsen et al., 1972]) document an onset of warming in both hemispheres between 21.3-20.5 kyr B.P. (Figure 5d). Warming at $\sim 22 \mathrm{kyr}$, by some $\sim 6^{\circ} \mathrm{C}$ over a few decades, is also recorded in the Siple Dome $\delta \mathrm{D}$ profile located some $500 \mathrm{~km}$ from Byrd [Taylor et al., 2004]. An early warming trend is likewise apparent in planktonic $\delta^{18} \mathrm{O}$ from DAPC2 that steadily decreases from $21.5 \mathrm{kyr}$ B.P. for some 1000 years (Figure 5c). This trend is mirrored by a decrease in Nps percent (Figure 5b) that mimics the structure of the GISP2 $\delta^{18} \mathrm{O}$ record at that time. The decrease is terminated abruptly by an IRD event centered at 20.3 kyr B.P. (Figure 5a), coincident with a cold episode in GISP2 that is not displayed in the Byrd $\delta^{18} \mathrm{O}$ record. The trend of decreasing planktonic $\delta^{18} \mathrm{O}$ is then reestablished at $\sim 20.2 \mathrm{kyr}$ B.P. and proceeds for another 1000 years until halted once more by a further abrupt cold episode at 19 kyr B.P. This cold reversal is best displayed by the abrupt increase of Nps percent in DAPC2 and is also seen in the Byrd $\delta^{18} \mathrm{O}$ record. The two periods of northern hemisphere warming between 21.5 and $19 \mathrm{kyr}$ B.P. in our view represent the initial phase of global deglaciation that is clearly visible in the Byrd and other
Antarctic ice core records but was aborted twice in the North Atlantic by episodes of enhanced iceberg drift from the initial stages of the disintegrating North Atlantic ice sheets. The cooling at $\sim 19 \mathrm{kyr}$ B.P. therefore heralds the onset of an increasing and sustained climatic divergence between the hemispheres reflecting widespread cooling in the North Atlantic region.

[23] While deglacial warming proceeds in the south, Nps percent and planktonic $\delta^{18} \mathrm{O}$ in DAPC2 and $\delta^{18} \mathrm{O}$ in GISP2 show that glacial conditions continued and intensified in the North Atlantic region for another 4000 years. Over this period an enhanced iceberg productivity, reflected by a trend of increasing IRD flux suggests a progressive disintegration of the North Atlantic ice sheets (Figure 5a). The associated meltwater runoff appear to have impinged directly on the vigor of the Atlantic MOC [Clark et al., 2004] by suppressing the northward advection of oceanic heat and thereby prolonging glacial conditions in the wider North Atlantic region. The position of DAPC2 close to the former western BIS, and notably the direct linking of IRD events along the core with phases of glacial retreat in the British Isles, suggests that the breakup of the BIS contributed to this climatic pattern. Marine records from the southern Norwegian slope, documenting massive deposition of plumites and IRD between 18 and $21 \mathrm{kyr}$ [Lekens et al., 2005], further suggest that this initial phase of ice sheet decay affected the Eurasian Ice Sheet beyond the British Isles. The direct impact of an early ice sheet disintegration on the Atlantic MOC is demonstrated by ${ }^{231} \mathrm{~Pa}_{\mathrm{xs}}{ }^{230} \mathrm{Th}_{\mathrm{xs}}$ records from DAPC2 [Hall et al., 2006] showing an onset of MOC slow down between 1.2 and $1.3 \mathrm{kyr}$ prior to the deposition of HE1. It was not until the end of IRD deposition and the ensuing meltwater surge that the MOC intensified and the North Atlantic region abruptly warmed during the Bølling period at 14.7 kyr B.P. [Clark et al., 2004; Weaver et al., 2003].

\subsection{Mechanisms for Rapid Ice Sheet Instability}

[24] The series of short-lived IRD events that are recorded in DAPC2 prior to HE1 and HE2 document recurrent episodes of iceberg discharges lasting some 80-100 years. The events likely represent periods of abrupt destabilization of marine based segments of the BIS. The collapse of ice shelves that buttress major ice sheets today have alluded to the role of ice shelf thinning and their subsequent collapse in initiating rapid ice flow leading to enhanced iceberg production [Scambos et al., 2000; Shepherd et al., 2003; Vaughan and Doake, 1996]. Such a mechanism has been proposed as a modern analogue for the events leading up to the sudden collapse of the LIS and the occurrence of Heinrich events [Hulbe et al., 2004]. The rapid "precursor" IRD events seen in DAPC2 may indeed represent the sedimentological footprint of collapsing ice shelves fringing the BIS that resulted in sudden and high-volume production of debris laden icebergs [Hulbe et al., 2004]. The fast SST oscillations inferred from faunal and stable isotope proxies in DAPC2 support such an ice shelf mechanism for the short-lived IRD events in that they are consistent with episodes of surficial (atmospheric-driven) and basal (ocean-driven) melting that play lead roles in precondition- 


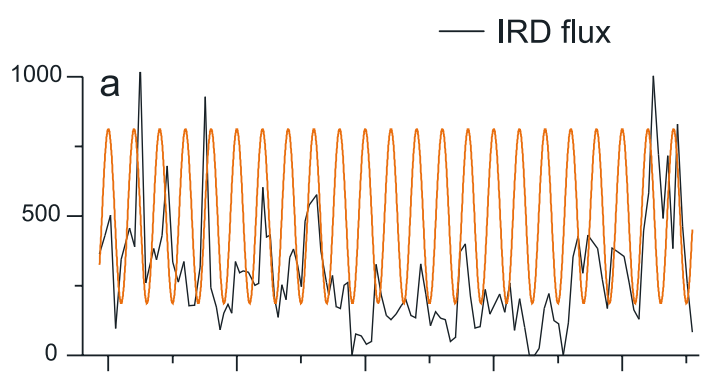

- 200-yr sine wave
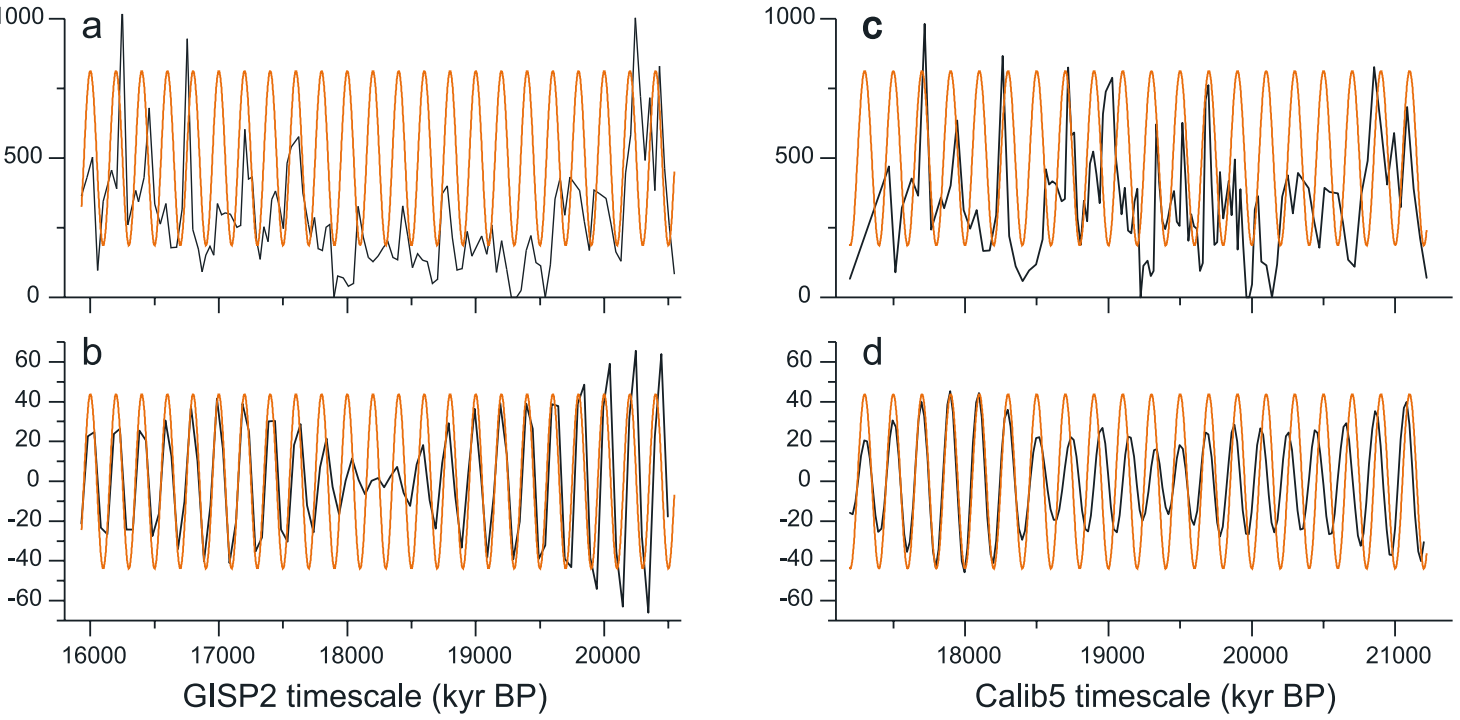

Figure 7. The 200 year sine wave compared to (a) the quartz IRD flux and (b) band-pass-filtered quartz IRD flux from core DAPC2 on the GISP2 timescale. (c) and (d) Equivalent flux comparisons on the DAPC2 Calib5 timescale. Gaussian band-pass filtering was performed using AnalySeries [Paillard et al., 1996] at a central frequency of 0.005 years and bandwidth of 0.0005 years. Differences in IRD flux amplitude between Figures $7 \mathrm{a}$ and $7 \mathrm{~b}$ and Figures $7 \mathrm{c}$ and $7 \mathrm{~d}$ reflect the difference in accumulation rates determined by the two age models (Figure $2 \mathrm{a}$ ).

ing ice shelves toward thinning and collapse [Hindmarsh and Jenkins, 2001; Vaughan and Doake, 1996]. Northward advection of heat and moisture associated with these abrupt ocean climate warmings would further exert a critical control on glacial mass balances in NW Europe [Boulton et al., 2001; Siegert and Marsiat, 2001] potentially reinforcing the dynamic response to ice margin instabilities.

[25] A mechanism involving an oscillating ice margin around the BIS is supported by geological evidence from the Hebrides margin and the Celtic Sea. On the west Shetland shelf a series of overlapping morainal ridges interdispersed with glaciomarine muds (Otter Bank sequence) document progressive ice sheet retreat during the final stage of the last glacial period [Stoker and Holmes, 1991]. Sonar data show that these sequences and the entire shelf margin at 200-500 m water depth is crosscut by iceberg plough marks [Masson, 2001] indicating periods of iceberg calving along a wide glacial marine margin. Similar submarine features in the Celtic sea [Belderson et $a l ., 1973]$, and the observation of deformed till deposits on the south Irish coast [Cofaigh and Evans, 2001], is indicative of a major Irish Sea ice stream draining the southwest sector of the BIS. If at their distal ends these marine based glacial outlets were anchored on the continental shelf this would have left them particularly vulnerable to small increases in sea level and ocean temperature. Following the disintegration of their buttressing section along marine grounding lines additional production of icebergs would ensue from fast flowing ice streams draining the central ice dome.

[26] Correlation between increasing IRD flux between 19 and $15 \mathrm{kyr}$ B.P. and rising $65^{\circ} \mathrm{N}$ insolation suggests a linkage between the early disintegration of the BIS and a gradual but sustained increase in solar radiative forcing during this period (Figure 5a). Solar forcing has been suggested previously as an underlying external factor for millennial-scale climate change [Bond et al., 2001; Braun et $a l ., 2005]$ and a range of decadal to centennial-scale modes observed in ${ }^{14} \mathrm{C}$ productivity records have likewise been linked to solar variability [Drazin and King, 1992; Stuiver and Braziunas, 1989]. Gaussian band-pass filtering of the IRD quartz flux from DAPC2 (Figures 7a-7d) suggests that the pattern of recurrent IRD peaks across the early deglaciation falls within the de Vries-Suess solar band of a primary 180-220 year cyclicity [Wagner et al., 2001]. This relationship is observed for both the tuned GISP2 age scale and the untuned calibrated ${ }^{14} \mathrm{C}$ chronology, hence it appears to be a robust feature of the DAPC2 IRD flux record. Solar forcing of BIS instability cannot be confirmed unambiguously because proxy profiles of solar variability such as cosmogenic ${ }^{10} \mathrm{Be}$ along the Greenland ice cores [Beer et al., $2000,2002]$ do not currently resolve variability between 19 and $15 \mathrm{kyr}$ at sufficient temporal resolution. Nonetheless, the Greenland ${ }^{10} \mathrm{Be}$ record resolves a de Vries cyclicity in the interval 25-50 kyr B.P. where temporal resolution is high [Wagner et al., 2001], suggesting that solar radiation indeed varied within the de Vries-Suess periodicity band. The assertion that the centennial IRD cycles in DAPC2 are related to external forcing rather than internal ice sheet dynamics, is reinforced by evidence of similar duration cycles in other Northern Hemisphere sedimentary archives, notably lake records from Alaska [Hu et al., 2003], the Dead Sea rift [Prasad et al., 2004], and the Guliya ice core from western Tibet [Thompson et al., 1997]. Highamplitude $\delta^{18} \mathrm{O}$ oscillations in the Guliya ice core occur with an apparent periodicity of 200 years during the glacial 
interval (15-33 kyr) suggesting a possible linkage with solar proxies in the Greenland ice cores. These studies, combined with our records, lend credence to the contention that a de Vries-Suess type cyclicity may have contributed to glacial climate variability through its interference with ocean climatology and ice sheet stability. Relatively small changes in solar radiation budgets may influence climate through their perturbing impact on planetary waves that modulate, for instance, the index state of the Arctic/North Atlantic Oscillation (AO/NAO) [Hu et al., 2003; Shindell et $a l ., 2001]$. Model experiments in conjunction with observations [Shindell et al., 2001] suggest a direct control by $\mathrm{AO} / \mathrm{NAO}$ on the flux of moisture to the high latitudes and terrestrial climate. Such changes may thus have acted as amplifiers and transmitters of weak insolation forcing on midlatitude marine-based ice sheets.

[27] Recurrent collapses of the BIS at the onset of the last deglaciation may serve as a past analogue for the dynamic response of a mobile and metastable ice sheet under the influence of climate warming. The West Antarctic and Greenland ice sheets currently experience accelerated flow of several of their ice streams and enhanced loss of ice volume which have been linked with warming and thinning of regional glaciers [Hanna et al., 2005; Luckman et al., 2006; Rignot and Kanagaratnam, 2006; Shepherd et al., 2003; Zwally et al., 2002]. The BIS response to global warming during the last deglaciation suggests that these current glaciological patterns may represent but one of a sequence of future transient instability events, each multidecadal to century scale in duration. The marine-based West Antarctic ice sheet is particularly sensitive as its margins are exposed directly to changing ocean climatology and sea level changes that further add to the detrimental influence of atmospheric warming on ice sheet stability.

\section{Conclusions}

[28] Core DAPC2 from the northeast Atlantic margin reveals a detailed, multidecadal series of paleoceanographic proxies representing the late glacial and the last deglaciation, 10-27 kyr. Our proxy records show evidence of oceanographic changes that correspond to northern hemisphere climate oscillations, as known from the Greenland ice cores, and regional ice sheet variability in northwest Europe.

[29] We find evidence that the BIS progressively disintegrated 19-16 kyr B.P. generating abrupt iceberg and meltwater discharges starting some 2000 years prior to HE1. Peak sediment deposition from icebergs were short lived (80-100 years) and recurred at 180-220 year intervals, plausibly involving breakup of glacial tidewater margins and fringing marine ice shelves. A similar pattern of centennial-scale iceberg pulses is observed prior to HE2, 26-24 kyr B.P., suggesting repeated instabilities of marinebased glacial margins in the northeast Atlantic. The apparent $\sim 200$ year periodicity suggests a possible linking with de Vries-Suess insolation cycles.

[30] Comparisons of paleoclimate records indicate a global onset of early warming between 21 and $22 \mathrm{kyr}$ B.P. associated with increased insolation and seasonal temperature contrast. Superimposed on the long-term insolation driven climate forcing we observe a series of rapid multidecadal sea surface warmings across the LGM and early deglaciation that likely contributed to the instability of the BIS. A direct response to increasing insolation during the early deglaciation points to an inherently metastable BIS promoted by a persistent influence from marine heat and moisture. Through its proximity to convection centers in the northern North Atlantic recurrent meltwater surges directly impacted on the Atlantic MOC and made the BIS an essential component in regional climate and bipolar climate asymmetry. A prominent consequence of this ice-ocean interaction was to maintain cold glacial climates in the North Atlantic beyond the initial synchronous onset of deglaciation in both hemispheres. The ice-ocean-climate coupling that we identify in the northeast Atlantic did not occur in isolation but was amplified by buoyancy forcing from much larger ice sheets, notably the Laurentide Ice Sheet during the Heinrich events.

[31] An early response of the BIS, and possibly of other parts of the Eurasian Ice Sheet, alludes to their role as an amplifier and transmitter of centennial-scale climate forcing. If so, these patterns of ice-ocean interaction may serve as a past analogue for the current and prospective future response of modern ice sheets to a warming climate, such as the marinebased West Antarctic Ice Sheet or the Greenland Ice Sheet.

[32] Acknowledgments. P.C.K. acknowledges support through a fellowship from the Danish Research Agency. I.H. and R.Z. acknowledge support from NERC (grant NER/A/S/2001/00485) and the Ministerio de Educación y Ciencia, Spain (grant REN2002-01958CLI). We thank Mark Siddall and an anonymous reviewer for their helpful reviews. Comments by Peter Ditlevsen on an early version of the manuscript were highly appreciated.

\section{References}

Allen, J. R. M., et al. (1999), Rapid environmental changes in southern Europe during the last glacial period, Nature, 400, 740-743.

Andrews, J. T. (1998), Abrupt changes (Heinrich events) in late Quaternary North Atlantic marine environments:A history and review of data and concepts, J. Quat. Sci., 13, 3-16.

Andrews, J. T., and K. Tedesco (1992), Detrital carbonate-rich sediments, northwestern Labrador Sea: Implications for ice-sheet dynamics and iceberg rafting (Heinrich) events in the North Atlantic, Geology, 20, 1087-1090.
Andrews, J. T., D. C. Barber, and A. E. Jennings (1999), Errors in generating time series and in dating events at late Quaternary millennial (radiocarbon) time series: Examples from Baffin Bay, NW Labrador Sea, and East Greenland, in Mechanisms of Global Climate Change at Millennial Time Scales, edited by P. U. Clarke, R. S. Webb, and L. D. Keigwin, pp. 23-33, AGU, Washington, D. C.

Austin, W. E. N., and D. Kroon (1996), Late glacial sedimentology, foraminifera and stable isotope stratigraphy of the Hebridean Conti- nental Shelf, northwest Scotland, in Late Quaternary Palaeoceanography of the North Atlantic Margins, edited by J. Andrews et al., Geol. Soc. London Spec. Publ., 111, 187-213.

Bard, E., M. Arnold, R. G. Fairbanks, and B. Hamelin (1993), Th-230-U-234 and C-14 ages obtained by mass-spectrometry on corals, Radiocarbon, 35, 191-199.

Bard, E., M. Arnold, J. Mangerud, M. Paterne

L. Labeyrie, J. Duprat, M. A. Melieres,

E. Sonstegaard, and J. C. Duplessy (1994),

The North Atlantic atmosphere-sea surface 
${ }^{14} \mathrm{C}$ gradient during the Younger Dryas climatic event, Earth Planet. Sci. Lett., 126, 275-287. Beer, J., W. Mende, and R. Stellmacher (2000), The role of the Sun in climate forcing, Quat. Sci. Rev., 19, 403-415.

Beer, J., R. Muscheler, G. Wagner, C. Laj, C. Kissel, P. W. Kubik, and H. A. Synal (2002), Cosmogenic nuclides during isotope stages 2 and 3, Ouat. Sci. Rev., 21, 1129-1139.

Belderson, R. H., N. H. Kenyon, and J. B. Wilson (1973), Iceberg plough marks in the NE Atlantic, Palaeogeogr. Palaeoclimatol. Palaeoecol., 13, 215-224.

Blunier, T., and E. J. Brook (2001), Timing of millennial-scale climate change in Antarctica and Greenland during the last glacial period, Science, 291, 109-111.

Bond, G. C., and R. Lotti (1995), Iceberg discharges into the North Atlantic on millennial time scales during the last glaciation, Science, 267, 1005-1010.

Bond, G., et al. (1992), Evidence for massive discharges of icebergs into the North Atlantic ocean during the last glacial period, Nature, $360,245-249$.

Bond, G., W. Broecker, S. Johnsen, J. Macmanus, L. Labeyrie, J. Jouzel, and G. Bonani (1993), Correlations between climate records from North Atlantic sediments and Greenland ice, Nature, 365, 143-147.

Bond, G., B. Kromer, J. Beer, R. Muscheler, M. N. Evans, W. Showers, S. Hoffmann, R. Lotti-Bond, I. Hajdas, and G. Bonani (2001), Persistent solar influence on north Atlantic climate during the Holocene, Science, 294, 2130-2136.

Boulton, G. S., P. Dongelmans, M. Punkari, and M. Broadgate (2001), Palaeoglaciology of an ice sheet through a glacial cycle, Quat. Sci. Rev., 20, 591-625.

Bowen, D. Q., F. M. Phillips, A. M. McCabe, P. C. Knutz, and G. A. Sykes (2002), New data for the Last Glacial Maximum in Great Britain and Ireland, Quat. Sci. Rev., 21, 89-101.

Braun, H., M. Christl, S. Rahmstorf, A. Ganopolski, A. Mangini, C. Kubatzki, K. Roth, and B. Kromer (2005), Possible solar origin of the 1,470-year glacial climate cycle demonstrated in a coupled model, Nature, 438, 208-211.

Broecker, W. S., G. Bond, M. Klas, E. Clark, and J. McManus (1992), Origin of the northern Atlantic's Heinrich events, Clim. Dyn., 6, 265-273

Clark, P. U., A. M. McCabe, A. C. Mix, and A. J. Weaver (2004), Rapid rise of sea level 19,000 years ago and its global implications, Science, 304, $1141-1144$.

Clemens, S. C. (2005), Millennial-band climate spectrum resolved and linked to centennialscale solar cycles, Quat. Sci. Rev., 24, 521-531.

Cofaigh, C. O., and D. J. A. Evans (2001), Deforming bed conditions associated with a major ice stream of the last British ice sheet, Geology, 29, 795-798.

Dansgaard, W., and H. Oeschger (1989), Past environmental long-term records from the Arctic, in The Environmental Record in Glaciers and Ice Sheets, edited by $\mathrm{H}$. Oeschger and C. Langway, pp. 287-318, John Wiley, Hoboken, N. J.

Dokken, T. M., and E. Jansen (1999), Rapid changes in the mechanism of ocean convection during the last glacial period, Nature, 401, 458-461.

Drazin, P. G., and G. P. King (1992), Interpretation of time-series from nonlinear-systems: Introduction, Physica D, 58, R7-R11.
Ellett, D. J., and D. G. Roberts (1973), The overflow of Norwegian Sea Deep Water across the Wyville-Thomson Ridge, Deep Sea Res., 20, 819-835.

Elliot, M., L. Labeyrie, G. Bond, E. Cortijo, J. L. Turon, N. Tisnerat, and J. C. Duplessy (1998), Millennial-scale iceberg discharges in the Irminger Basin during the last glacial period: Relationship with the Heinrich events and environmental settings, Paleoceanography, $13,433-446$.

Fronval, T., E. Jansen, J. Bloemendal, and S. Johnsen (1995), Oceanic evidence for coherent fluctuations in Fennoscandian and Laurentide ice sheets on millennium timescales, Nature, 374, 443-446.

Ganopolski, A., and S. Rahmstorf (2001), Rapid changes of glacial climate simulated in a coupled climate model, Nature, 409, 153-158.

Genty, D., D. Blamart, R. Ouahdi, M. Gilmour, A. Baker, J. Jouzel, and S. Van-Exter (2003), Precise dating of Dansgaard-Oeschger climate oscillations in western Europe from stalagmite data, Nature, 421, 833-837.

Goni, M. F. S., I. Cacho, J. L. Turon, J. Guiot, F. J. Sierro, J. P. Peypouquet, J. O. Grimalt, and N. J. Shackleton (2002), Synchroneity between marine and terrestrial responses to millennial scale climatic variability during the last glacial period in the Mediterranean region, Clim. Dyn., 19, 95-105.

Grootes, P. M., and M. Stuiver (1997), Oxygen $18 / 16$ variability in Greenland snow and ice with $10^{-3}$ to $10^{5}$ year time resolution, $J$. Geophys. Res., 102, 26,455-26,470.

Grousset, F. E., C. Pujol, L. Labeyrie, G. Auffret, and A. Boelaert (2000), Were the North Atlantic Heinrich events triggered by the behavio of the European ice sheets?, Geology, 28 $123-126$

Hall, I. R., and J. Scourse (2005), Sequencing ocean-ice interaction, MD141 Cruise Report, 20 pp., Cardiff Univ., Cardiff, U. K.

Hall, I. R., S. B. Moran, R. Zahn, P. C. Knutz, C.-C. Shen, and R. L. Edwards (2006), Accelerated drawdown of meridional overturning in the late-glacial Atlantic triggered by transient pre-H event freshwater perturbation, Geophys. Res. Lett., 33, L16616, doi:10.1029/ 2006GL026239.

Hanna, E., P. Huybrechts, I. Janssens, J. Cappelen, K. Steffen, and A. Stephens (2005), Runoff and mass balance of the Greenland ice sheet: 1958-2003, J. Geophys. Res. 110, D13108, doi:10.1029/2004JD005641.

Heinrich, H. (1988), Origin and consequences of cyclic ice-rafting in the northeast Atlantic Ocean during the past $130 \mathrm{ka}$, Quat. Res. $29,142-152$.

Hemming, S. R. (2004), Heinrich events: Massive late Pleistocene detritus layers of the North Atlantic and their global climate imprint, Rev. Geophys., 42, RG1005, doi:10.1029/ 2003RG000128

Hindmarsh, R. C. A., and A. Jenkins (2001), Centurial-millennial ice-rafted debris pulses from ablating marine ice sheets, Geophys Res. Lett., 28, 2477-2480.

Hu, F. S., D. Kaufman, S. Yoneji, D. Nelson, A. Shemesh, Y. Huang, J. Tian, G. Bond, B. Clegg, and T. Brown (2003), Cyclic variation and solar forcing of Holocene climate in the Alaskan subarctic, Science, 301, 1890-1893.

Hulbe, C. L., D. R. MacAyeal, G. H. Denton, J. Kleman, and T. V. Lowell (2004), Catastrophic ice shelf breakup as the source of Heinrich event icebergs, Paleoceanography, 19, PA1004, doi:10.1029/2003PA000890.
Jansen, E., and T. Veum (1990), Evidence for two-step glaciation and its impact on North Atlantic deep-water circulation, Nature, 343, 612-616.

Johannessen, T., E. Jansen, A. Flatøy, and A. C. Ravelo (1994), The relationship between surface water masses, oceanographic fronts and paleoclimatic proxies in surface sediments of Greenland, Iceland, Norwegian Seas, in Carbon Cycling in the Glacial Ocean: Constraints on the Ocean's Role in Global Change: Quantitative Approaches in Paleoceanography, NATO ASI Ser. 1, vol. 17, edited by R. Zahn et al., pp. 61-85, Springer, New York.

Johnsen, S. J., W. Dansgaard, H. B. Clausen, and C. C. Langway Jr. (1972), Oxygen isotope profiles through the Antarctic and Greenland ice sheets, Nature, 235, 429-434.

Knutz, P. C., W. E. N. Austin, and E. J. W. Jones (2001), Millennial-scale depositional cycles related to British Ice Sheet variability and North Atlantic palaeocirculation since $45 \mathrm{ka} \mathrm{B}$. P. Barra Fan, U.K. margin, Paleoceanography, $16,53-64$

Knutz, P. C., I. R. Hall, R. Zahn, T. L. Rasmussen, A. Kuijpers, M. Moros, and N. J. Shackleton (2002), Multidecadal ocean variability and European ice sheet surges during the last deglaciation, Geochem. Geophys. Geosyst., 3(12), 1077 doi:10.1029/2002GC000351

Lehman, S. J., G. A. Jones, L. D. Keigwin, E. S. Andersen, G. Butenko, and S.-R. Østmo (1991), Initiation of Fennoscandian ice-sheet retreat during the last deglaciation, Nature, 349, 513-516.

Lekens, W. A. H., H. P. Sejrup, H. Haflidason, G. O. Petersen, B. Hjelstuen, and G. Knorr (2005), Laminated sediments preceding heinrich event 1 in the northern North Sea and southern Norwegian Sea: Origin, processes and regional linkage, Mar. Geol., $216,27-50$

Luckman, A., T. Murray, R. de Lange, and E. Hanna (2006), Rapid and synchronous icedynamic changes in East Greenland, Geophys. Res. Lett., 33, L03503, doi:10.1029/ 2005GL025428.

Masson, D. G. (2001), Sedimentary processes shaping the eastern slope of the Faeroe-Shetland Channel, Cont. Shelf Res., 21, 825-857.

McCartney, M. S. (1992), Recirculation components to the deep boundary current of the northern North Atlantic, Prog. Oceanogr., 29 283-383.

Meese, D. A., A. J. Gow, R. B. Alley, G. A. Zielinski, P. M. Grootes, M. Ram, K. C Taylor, P. A. Mayewski, and J. F. Bolzan (1997), The Greenland Ice Sheet Project 2 depth-age scale: Methods and results, J. Geophys. Res., 102, 26,411-26,423.

New, A. L., and D. Smythe-Wright (2001) Aspects of the circulation in the Rockall Trough, Cont. Shelf Res., 21, 777-810.

Paillard, D., L. Labeyrie, and P. Yiou (1996), Macintosh Program performs time-series analysis, Eos Trans. AGU, 77, 379

Peck, V. L., I. R. Hall, R. Zahn, H. Elderfield, F. Grousset, S. R. Hemming, and J. D Scourse (2006), High resolution evidence for linkages between NW European ice sheet instability and Atlantic Meridional Overturning Circulation, Earth Planet. Sci. Lett., 243, 476-488.

Prasad, S., H. Vos, and J. F. W. Negendank (2004), Evidence from Lake Lisan of solar influence on decadal- to centennial-scale climate variability during marine oxygen isotope stage 2, Geology, 32, 581-584. 
Rignot, E., and P. Kanagaratnam (2006), Changes in the velocity structure of the Greenland ice sheet, Science, 311, 986-990.

Ruddiman, W. F. (1977), Late Quaternary deposition of ice-rafted sand in the subpolar North Atlantic (lat 40 to 65 N), Geol. Soc. Am. Bull., 88, 1813-1827.

Scambos, T. A., C. Hulbe, M. Fahnestock, and J. Bohlander (2000), The link between climate warming and break-up of ice shelves in the Antarctic Peninsula, J. Glaciol., 46, 516-530.

Scourse, J. D., I. R. Hall, I. N. McCave, J. R. Young, and C. Sugdon (2000), The origin of Heinrich layers: Evidence from $\mathrm{H} 2$ for European precursor events, Earth Planet. Sci. Lett., 182, $187-195$.

Sevastopulo, G. D. (1981), Lower Carboniferous, in A Geology of Ireland, edited by C. H. Holland, pp. 147-171, Scott. Acad., Edinburgh, U. K.

Shackleton, N. J., and N. D. Opdyke (1973), Oxygen isotope and palaeomagnetic stratigraphy of equatorial Pacific core V28-238: Oxygen isotope temperature and ice volumes on a $10^{5}$ year and $10^{6}$ year scale, Quat. Res., 3, $39-55$.

Shackleton, N. J., M. A. Hall, and E. Vincent (2000), Phase relationships between millennial-scale events $64,000-24,000$ years ago, Paleoceanography, 15, 565-569.

Shepherd, A., D. Wingham, T. Payne, and P. Skvarca (2003), Larsen ice shelf has progressively thinned, Science, 302, 856-859.

Shindell, D. T., G. A. Schmidt, M. E. Mann, D. Rind, and A. Waple (2001), Solar forcing of regional climate change during the Maunder Minimum, Science, 294, 2149-2152.

Siegert, M. J., and I. Marsiat (2001), Numerical reconstructions of LGM climate across the
Eurasian Arctic, Ouat. Sci. Rev., 20, 1595 1605 .

Stocker, T. F., and D. G. Wright (1996), Rapid changes in ocean circulation and atmospheric radiocarbon, Paleoceanography, 11, 773-795.

Stoker, M. S., and R. Holmes (1991), Submarine end moraines as indicators of Pleistocene ice-limits off northwest Britain, J. Geol. Soc London, 148, 431-434.

Stuiver, M., and T. F. Braziunas (1989), Atmospheric C-14 and century-scale solar oscillations, Nature, 338, 405-408.

Stuiver, M., and P. J. Reimer (1993), Extended C-14 data-base and revised CALIB 3.0 C-14 age calibration program, Radiocarbon, 35 , 215-230.

Taylor, K. C., et al. (2004), Abrupt climate change around $22 \mathrm{ka}$ on the Siple Coast of Antarctica, Quat. Sci. Rev., 23, 7-15.

Thompson, L. G., T. Yao, M. E. Davis, K. A Henderson, E. Mosley-Thompson, P. N. Lin, J. Beer, H. A. Synal, J. ColeDai, and J. F. Bolzan (1997), Tropical climate instability: The last glacial cycle from a Qinghai-Tibetan ice core, Science, 276, 1821-1825.

van Kreveld, S., M. Sarnthein, H. Erlenkeuser, P. Grootes, S. Jung, M. J. Nadeau, U. Pflaumann, and A. Voelker (2000), Potential links between surging ice sheets, circulation changes, and the Dansgaard-Oeschger cycles in the Irminger Sea, 60-18 kyr, Paleoceanography, 15, 425-442.

Vaughan, D. G., and C. S. M. Doake (1996), Recent atmospheric warming and retreat of ice shelves on the Antarctic Peninsula, Nature, 379, 328-331.

Voelker, A. H. L., M. Sarnthein, P. M. Grootes, H. Erlenkeuser, C. Laj, A. Mazaud, M. J. Nadeau, and M. Schleicher (1998), Correlation of marine $\mathrm{C}-14$ ages from the Nordic seas with the GISP2 isotope record: Implications for C-14 calibration beyond $25 \mathrm{ka} \mathrm{BP}$, Radiocarbon, 40, 517-534

Waelbroeck, C., J. C. Duplessy, E. Michel, L. Labeyrie, D. Paillard, and J. Duprat (2001), The timing of the last deglaciation in North Atlantic climate records, Nature, 412 724-727.

Wagner, G., J. Beer, J. Masarik, R. Muscheler, P. W. Kubik, W. Mende, C. Laj, G. M. Raisbeck, and F. Yiou (2001), Presence of the solar de Vries cycle (similar to 205 years) during the last ice age, Geophys. Res. Lett., 28, 303-306.

Weaver, A. J., O. A. Saenko, P. U. Clark, and J. X. Mitrovica (2003), Meltwater pulse 1A from Antarctica as a trigger of the Bolling-Allerod warm interval, Science, 299, 1709-1713.

Zwally, H. J., W. Abdalati, T. Herring, K. Larson, J. Saba, and K. Steffen (2002), Surface meltinduced acceleration of Greenland ice-sheet flow, Science, 297, 218-222.

I. R. Hall, School of Earth, Ocean and Planetary Sciences, Cardiff University, Main Building, Park Place, Cardiff CF710 3YE, UK.

P. C. Knutz, Geological Survey of Denmark and Greenland, Øster Voldgade 10, DK-1350 Copenhagen K, Denmark. (pkn@geus.dk)

R. Zahn, Institució Catalana de Recerca y Estudis Avançats y Universitat Autònoma de Barcelona, Institut de Ciencia y Tecnologia Ambientals, Edifici Cn - Campus UAB, Bellaterra, E-08193, Spain. 